\title{
COVID-19 Pandemic of 2020: Prevention and Public Health Policy
}

\author{
Robert W Buckingham* and Renata Ferretti \\ University of Michigan, Flint, Michigan, United States \\ *Corresponding Author: Robert W Buckingham, University of Michigan, Flint, \\ Michigan, United States.
}

Received: May 18, 2020

Published: June 12, 2020

(C) All rights are reserved by Robert W

Buckingham and Renata Ferretti.

\begin{abstract}
The world is now facing a pandemic crisis of COVID-19. This pandemic has awakened the consciousness of many countries that have not prioritized their public health and prevention policies and practices. European countries were devastated by Covid-19, and the United States of America (U.S.A.) is presently the country with the highest number of cases and fatalities. It is the time for many countries to reassess the importance of public health and preventive strategies. This is also the time for large economies to consider a reallocation resources from military establishment to public health preventive initiatives. The study is secondary research and aims to analyze how countries have invested resources in prevention and public health.
\end{abstract}

Keywords: Public Health; Preventive Health Services; Pandemics; Coronavirus; Healthcare Financing

\section{Introduction}

The world population eagerly awaits more details with each passing day about the growing cases and fatalities of the mysterious coronavirus COVID-19. There are more than 4.5 million cases worldwide and 307 thousand deaths, according to the World Health Organization - WHO (2020). We had to modify our behavior of how we meet and greet people, maintain social distance, amend our daily routines, and cautiously travel in the hope to reduce transmission of the virus. Individual freedoms, such as our freedom of movement, to assemble and perhaps the right of privacy, which we hold so dearly, is compromised.

Many people have equated the Covid-19 pandemic as to a war. European countries like Italy, Spain, and England were devastated by Covid-19, and the United States of America (U.S.A.) is the country with the highest number of cases and victims of fatality. Currently the world faces a pandemic crisis on unknow proportions. Why were we not prepared?

\section{Virus and the pandemic}

In the present context, COVID-19 $\mathrm{s}$ is a global threat, a pandemic. It is a life-threatening disease and has acted as a war against humanity, that cannot be won by arms and ammunitions, but rather a good healthcare plan and disease prevention policies. In a pandemic situation, no country can afford to have a weak public health preparedness system. The Covid-19 pandemic started in China and now is affecting 199 countries and territories around world, how it is possible to see in the figure 1, the epidemic curve of confirmed Covid-19 [1].

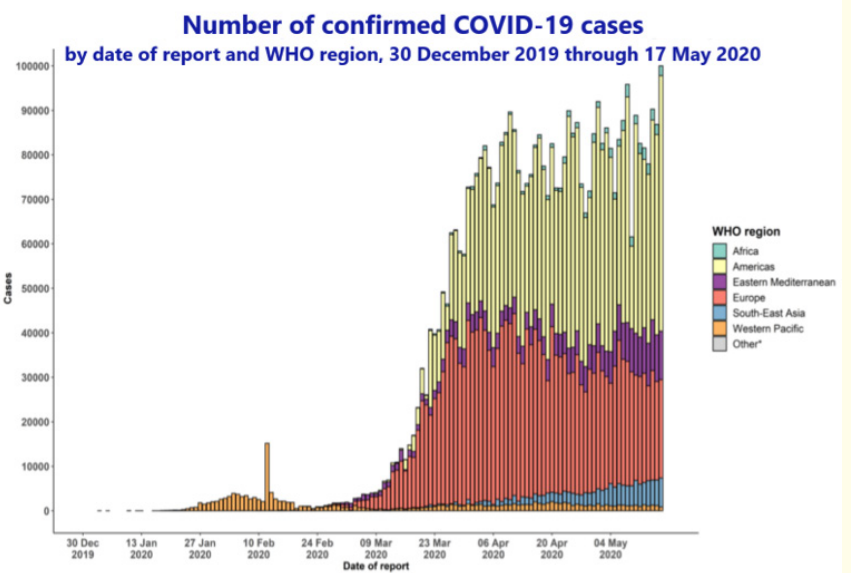

Figure 1: Number of confirmed COVID-19 cases [1].

Coronavirus is a large group of viruses common among animals (WHO, 2020). This is a zoonotic disease since it appears to have been transmitted from animal to human, at an open-air animal market in Wuhan, China [2]. Phylogenetic analysis suggests that bats are the reservoir of the COVID-19 virus, but more research is being carried out to identify the intermediate host(s) [2]. Even though the COVID-19 is not as deadly as other coronaviruses like SARS-Cov, it appears to be more transmissible [3]. On May $17^{\text {th }}$, 
2020, there are more than 4.5 million cases worldwide and 307 thousand deaths, which means that the mortality rate is about $7 \%$, for those who contract the virus [1].

\section{World health care expenditure for prevention of pandemics}

In the coronavirus pandemic, health systems around the world are being tested. Some countries are having better results in lives and costs because they had invested more resources in prevention before the pandemic. Others will face more challenges and will have their health system overloaded because, in the past, countries had preferred to invest in medical treatment.

Nowadays, with the occurrence of the pandemic of COVID-19, the prevention started to assume a position of much more prominence: The whole world is valuing the importance of public health. According to Gmeinder., et al. [4] "Prevention and public health policies are a key pillar of any modern health system" (2017, p. 9). However, the expenditure on health promotion and disease prevention is so short around the world. In 2015, the average of allocating in health promotion and disease prevention was only $2,8 \%$ of the total health spending by the countries members of the Organization for Economic Co-operation and Development (OECD) [5]. What can be seen in figure 2, in this $2,8 \%$ of spending in health promotion and disease prevention by countries, in average: $9 \%$ was allocated to immunization; $7 \%$ on early disease detection; $44 \%$ on healthy condition monitoring; $27 \%$ on information, education and counseling; and $13 \%$ on other collective services [4].

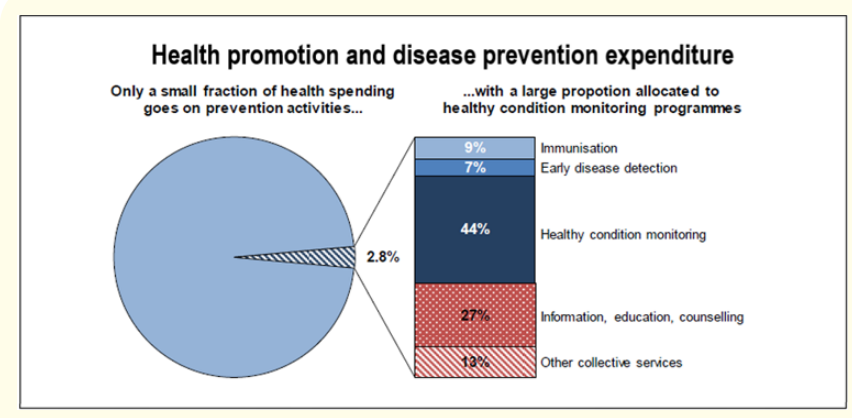

Figure 2: Health Promotion and disease preventions expenditure ([4], p. 6).

Prevention and public health policies have reached great importance with the aging of societies around the world with numerous cases of chronic diseases such as cardiovascular diseases, musculoskeletal disorders, cancer, and diabetes. Among the OECD member countries, the main financers of preventive care are the governments and compulsory health insurance [4]. In 2015, gov- ernment schemes covered, on average, $64 \%$ of prevention expenditure, which indicates higher public coverage of preventive care services compared to other health care services. Even in countries where mandatory insurance covers significant portions of spending on prevention, some vital public health activities are funded and organized by the central, regional, or local governments. However, after the 2008 world economic crisis, the OECD countries' investment with prevention decreased. The OECD countries decreased the spending on prevention from $6 \%$ of the GDP per capita to $-4 \%$ of 2010 . In 2014 and 2015 , the expenditure on prevention increased to around 2,8\% per country [4].

The total health care bill to health promotion and disease prevention is much less than what countries spending on other health care functions. Most of the care bill is allocated to treatment, including curative and rehabilitative care services $(60,3 \%)$ and medical goods $(19,6 \%)$. The OECD countries are estimated to have spent on average $8.8 \%$ of GDP on health care in 2018. In 2018, the U.S.A. spent the equivalent to $16.9 \%$ of its GDP on health care, followed by Switzerland that spent $12.2 \%$ and a group of high-income countries (Germany, France, Sweden, and Japan) that all spent close to $11 \%$ of their GDP on health care. Although it appears that some countries make a high investment in health, this does not mean that governments are responsible for spending on health. For instance, according to the OECD, the U.S.A. government is responsible for only $26 \%$ of health financing, while the average for other OCDE members is around $36 \%$ of government spending on health spending [4].

Countries with high health expenditures are not necessarily a perfect indicator of the best results of health services. It is important to analyze other indicators such as numbers of health workers, quality and access to care, avoidable mortality rates, efficient use of health resources, and the wider social determinants of health. With this level of criticism that we must analyze the countries' health indicators. For example, the U.S.A. spends for health is considerably more than in any other country in the world, which was over USD 10.000 per person in 2017, but the U.S.A. has the worse avoidable mortality rates than the OECD average and a lower population coverage of health.

\section{U.S. public health and military spending disparity}

The U.S. has the highest number of COVID-19 cases in the world, which figuratively more than 1.4 million, with eighty-five thousand deaths on May 17, 2020. To the country, nothing could be worse for the U.S.A. than having a weak health care system. However, over the last years, the U.S. has chosen to invest billions of dollars 
in defense and the military and so little to public health prevention. In 2019, according to Congressional Budget Office - CBO [6] the United States spent 66 billion of dollars of the discretionary budget on health spending, while the country spent 676 billion of dollars of its budget on defense spending (Figure 3). The red arrows in figure 3 help to quickly find the numbers so disparate between investments in defense and investments in health. The U.S.A. invests around ten times more expenditure estimated for military and defense than the health care and human services. Henceforth, the decision will weaken the health care system of the U.S.A. at this time of need.

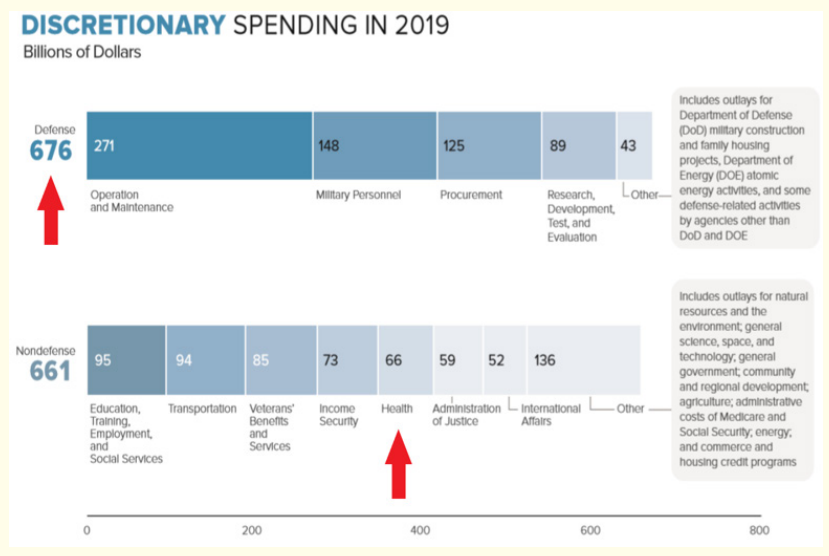

Figure 3: 2019 discretionary spending in 2019 [6].

The United States of America has seen some significant cuts in the budgets for public health funding in recent years. The United States' public health efforts are about $\$ 4.5$ billion underfunded, according to The Trust for America's Health [7]. In 2018, the U.S. government proposed a budget cut of almost $18 \%$ to the U.S.A. Department of Health and Human Services (HHS). Also, the U.S. government dismissed the entire pandemic response chain of command and cut national health expenditures by $\$ 15$ billion and the global disease-fighting operating budgets of leading government health organizations [8]. However, low public investment in health has left state and local health departments unprepared to address public health emergencies such as infectious disease outbreaks as COVID-19, extreme weather events, and the opioid crisis [9].

In 2016, Public Health Emergency Preparedness program funding was $\$ 660$ million which had decreased from $\$ 1.03$ billion [10]. The Public Health and Prevention Fund, what is designed to expand and sustain the nation's investment in public health and prevention, remains halfway to where it should have been financed in 2020 Fiscal Year due to the reallocation of money to other spend- ing programs $[11,12]$. Of the total national health expenditures in the U.S.A., less than three percent of expenditures are directed to public health and prevention, which corresponds to approximately $\$ 286$ per person $[12,13]$.

\section{Recommendations}

To protect the citizens from such life-threats and to support the global public health cause large economies must shift their attention to health care preventive programs. The key to keep the population safe and save money by preventing injury and illness is to invest more in public health and prevention. However, the countries' expenditure on health promotion and disease prevention is decreasing since the world economic crisis of 2008, and it is around $2,8 \%$ of the total health spending by the countries members of the Organization for Economic Co-operation and Development (OECD). In view of these findings, we recommend the big economies to invest more funding to health promotion and disease prevention as the level before the economic crisis of 2008 , that was around $6 \%$ of their GPD. More investment with health professionals, researchers and public health infrastructure would have prevented the current surge and spread of pandemics as well as solved the shortage of health professional, equipment, and facilities.

Presently the United States public health initiatives have been constantly diminished over the years which is now causing severe problems to its population. The impact of the major reductions in the budgets for public health funding did not surface until something significant like COVID-19 occurred. A rebalancing of U.S.A. military and healthcare spending would allow the Government to deal against the massive spread of the COVID-19 and to establish better infrastructure in the communities that need the most.

Finally, we suggest six rules to address the COVID-19 pandemic:

- Rule 1 - Hospitals must be prepared and supplied with PPE (personal protective equipment) such as masks, gowns, and face guards.

- $\quad$ Rule 2 - Test must be available to all people.

- $\quad$ Rule 3 - Contacts must be traced.

- $\quad$ Rule 4 - Quarantine when needed.

- $\quad$ Rule 5 - Government must be prepared to act quickly.

- Rule 6 - Utilization of private sector for assistance and support.

\section{Conclusion}

We as citizens of the world must prepare in advance since wars with an invisible enemy like COVID-19 are not announced. Pan- 
demics create a massive threat that countries cannot easily survive or tolerate. Most countries' health care system is focused on the treatment of disease rather than the prevention of disease. Currently, the population of the planet is on its knees. The entire world was unprepared for the Covid-19, mainly European countries and the U.S.A. and their leaders. What can we learn from this pandemic that has affected so many lives internationally? Prevention of disease is just as important as the treatment of disease. Is this not the time for our leaders of our respective countries reconsider this practice? Let us put more resources toward the prevention of disease. We need strong national leadership and put considerably more resources toward public health prevention of disease.

\section{Bibliography}

1. World Health Organization (WHO). "Coronavirus disease 2019 (COVID-19) Situation Report - 118” (2020).

2. World Health Organization (WHO). "Report of the WHO-China Joint Mission on Coronavirus Disease 2019 (COVID-19)” (2020).

3. Rehman SU., et al. "Evolutionary Trajectory for the Emergence of Novel Coronavirus SARS-CoV-2". Pathogens 9.3 (2020): 240.

4. Gmeinder M., et al. "How much do OECD countries spend on prevention?” OECD Health Working Papers No. 101 (2017).

5. OECD. "Health at a Glance 2019: OECD INDICATORS". OECD Publishing, Paris (2019).

6. Congressional Budget Office (CBO). "The Federal Budget in 2019: A closer look at discretionary spending" (2020).

7. Trust for America's Health (TFAH). "A Funding Crisis for Public Health and Safety: State-by-State Public Health Funding and Key Health Facts" (2017).

8. Garrett L. “Trump Has Sabotaged America's Coronavirus Response”. Foreign Policy online Newspaper (2020).

9. Johnson SR. "Report: Public health funding falls despite increasing threats". Modern Health Care (2019).

10. National Academies of Sciences, Engineering, and Medicine. "Infectious Diseases, Pandemic Influenza, and Antimicrobial Resistance: Global Health Security Is National Security." In Global Health and the Future Role of the United States. Washington, DC: National Academies Press (U.S.) (2017): 43-98.
11. The Balance. "FY 2020 Federal Budget: Trump's Budget Request" (2020).

12. Trust for America's Health (TFAH). "The Impact of Chronic Underfunding on America's Public Health System: Trends, Risks, and Recommendations, 2020" (2020).

13. Centers for Disease Control and Prevention (CDC). “CDC - Budget request overview: FY 2020 President's Budget Request \$6.594 Billion" (2020).

\section{Assets from publication with us}

- Prompt Acknowledgement after receiving the article

- Thorough Double blinded peer review

- Rapid Publication

- Issue of Publication Certificate

- High visibility of your Published work

Website: https://www.actascientific.com/

Submit Article: https://www.actascientific.com/submission.php Email us: editor@actascientific.com

Contact us: +919182824667 